\title{
RELIGION AND THE LOCAL TRADITION OF LIFE CYCLE RITUALS IN KAMPUNG NAGA, WEST JAVA
}

\author{
Abdurrahman Misno Bambang Prawiro \\ Al Hidayah State College of Islamic Studies, Bogor
}

\begin{abstract}
West Java is one of the provinces in Indonesia which is culturally rich and diverse. The cultural wealth in Tatar Sunda (West Java) is centered on several areas that serve as the settlement of indigenous communities, from the eastern region of Ciamis, to Sukabumi. Each region has its own cultural uniqueness. Among the cultural heritage which is still in existence and preserved is Kampung Naga. It was a traditional village that firmly preserves its ancestral tradition (karuhun) passed down from generation to generation. One of the interesting features of the community of Kampung Naga is the life cycle ritual which they perform with no outside influence. This article will describe the life cycle ritual performed by the indigenous community of Kampung Naga. The ethnographic method approach is used in this study, where the author was directly involved in the process of performing the ritual. Observations, in-depth interviews and participation in any activity were used to collect verifiable data. This research showed that the daur hidup (life cycle) ritual performed by the traditional community of Kampung Naga included the rituals for pregnant mother, child birth, circumcision, gusaran, marriage, and prayer to the dead. The ritual carried out by the community is derived from the old Sundanese belief combined with Islamic culture that came in later.
\end{abstract}

Keywords: Life Cycle Ritual, Kampung Naga, Traditional Community, Tatar Sunda

\section{INTRODUCTION}

West Java is one of the provinces in Indonesia which is culturally rich and diverse. Different tribes who populated this region have contributed to the unique culture as compared to other regions. The northern area of this province is inhabited by the tribal communities that originally came from Demak which controlled the region of Cirebon. In the following period, this region was occupied by descendants of the soldiers of the Mataram Kingdom in Central Java. In the region, the culture that thrives is Javanese culture mixed with others.

The southern part of the region is where the indigenous tribes of West Java, the Sundanese live. They are scattered in various areas with their own characteristics. However, they are bound in the bond of Sundanese ancestral 
culture. Sundanese culture developed to adapt the civilization of society, so to date it has slight differences in each region. Sundanese culture in Ciamis for example is different from that in Tasikmalaya, Garut, Bandung, Cianjur, Sukabumi or Bogor. The cultural centers are still well-preserved, particularly by people who live in traditional villages. One of the traditional villages in West Java is Kampung Naga which has its own uniqueness when compared to the other regions. This is due to minimal influence of outside cultures, so its culture is unmixed when compared to other regions.

Kampung Naga is one of the traditional villages where its people still preserve their ancestral traditions. They live without electricity, not using modern agricultural equipments and rejecting any form of foreign intervention which does not conform with the values of their culture. They also reject the use of LPG and prefer to cook with firewood. Their culture also prohibits the art that is unsuitable with their traditions. For example, they disallow dangdut music, western music, organ, puppet show, martial arts and all things foreign to their ancestors' common practice.

As a traditional community, they have a culture and rituals held in each week, month and year. In the field of agriculture, they have a lot of rituals beginning with rice planting until harvest time. Likewise, they have a life cycle ritual performed for various occasions such as pregnancy, child birth, aqiqa, circumcision, marriage and death. All are performed without any interference from cultures outside of their own. They believe that by carrying out these rituals, they have fulfilled the will of their ancestors, and this is a form of respect for them.

This paper aims to discuss the life cycle ritual performed by the community of Kampung Naga. This location was chosen since the community has not been affected by the beliefs and cultures outside of their own. In addition, they are also an indigenous community that continues to exist to date and is able to survive in the middle of the cultural changes in West Java in particular and in Indonesian society in general. By reviewing their life cycle ritual, we hope to learn about the local wisdom of the Indonesian people that may serve as a lesson for all of us.

\section{THE TRADITIONAL VILLAGE OF KAMPUNG NAGA}

Kampung Naga administratively is located in the area of RT 01 RW 01 Neglasari Village, Salawu Sub-district, Tasikmalaya Regency, West Java Province. The total area is 10 hectares consisting of a protected forest area of 3.5 hectares, land for settlement of more or less 1.5 hectares and for gardens 
and agriculture around 5 Hectares. The Position of the village, based on the GPS, lies on $7^{\circ} 21^{\prime} 30^{\prime \prime}$ S dan $107^{\circ} 59^{\prime} 30^{\prime \prime}$ E. When viewed using Google Earth, it lies on $7^{0} 21^{\prime} 37.02$ "S $107^{0} 59^{\prime \prime} 33.03^{\prime \prime T}$.

The geographical conditions of its territory are made up of valleys surrounded by hills, and the land surface in the western part is higher than that in the east. The Sundanese people call the condition of the land surface with the term taneuh bahe ngetan (condition of the land surface that has more contours sloping eastward as a result of land excavation directed eastward). Based on their belief, an area that has a slope is an ideal place, both for residential and agricultural land. Rationally, the belief makes sense because the area that has a slope of the land to the east will receive more morning sunlight. Therefore, people living there will be healthier due to the ultraviolet light in the morning. Kampung Naga has the boundaries as follows: to the east is the Ciwulan River and the opposite of it is elongated hills, called Bukit Naga (Dragon Hill). To the South of the village are rice fields and the entrance to the village. To the west are the hills among which the Makam Karamat (sacred tomb) is located, while To the north are the rice fields on the edge of the Ciwulan river. Kampung Naga is one of the villages located in the village of Neglasari, Salawu Sub-district, Tasikmalaya Regency, West Java Province. Neglasari is situated at an altitude of roughly $584 \mathrm{~m}$ above sea level. The distance from Neglasari to the center of the sub-district is approximately $5 \mathrm{~km}$, while the distance to the sub-district capital is around $17 \mathrm{~km}$, and it takes about 15 minutes to get to the sub-district capital using public transport while to get to the district capital is around 1 hour using public transport. The Map of Salawu Sub-district, Tasikmalaya Regency, West Java Province shows the position of Kampung Naga.

Neglasari is located on the provincial road that connects Tasikmalaya and Garut Districts, and is one of the villages belonging to the territory of Salawu Subdistrict, Tasikmalaya Regency. Astronomically, the coordinate of the area is $48 \mathrm{M} 0830263$ and UTM 9185211. The borders of Neglasari are as follows: to the north: Nangtang Village, Cigalontang sub-district, to the east: Karangmukti Village, to the south: Sundawenang Village and to the west: Tanjungsari Village.

Neglasari, now 102 years old, was originally named Pasir Angin, then renamed as Neglasari. The name is a combination of two areas, namely Negla Village on the west and Bantarsari village on the east. The person who united the two villages was Eyang Arbasan, a Bantarsari kuwu (village head). Kampung Naga is part of Naga Village, which is one of the four hamlets of the area Neglasari. Each village is headed by a village chief, who oversees several RW (wards) and RT (neighborhood associations). Kampung Naga head is Suharyo. While the 
RT chairman is Uron, and the RW Chairman, Munir. All government officials are housed in Kampung Naga as a center kadusunan.

Figure 1.

Neglasari Village Map

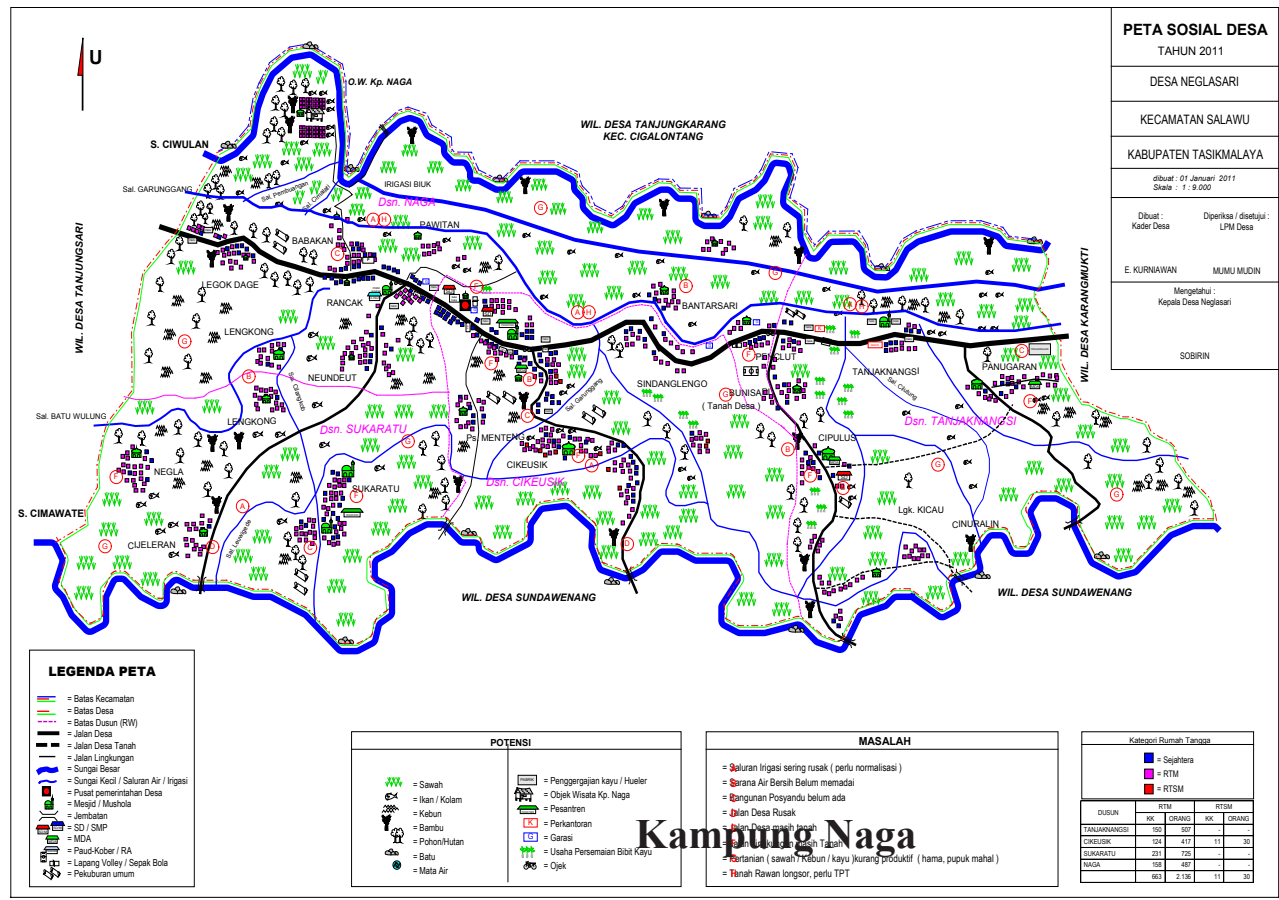

Source: Neglasari Village Document, Salawu Subdistrict, Tasikmalaya Regency

Neglasari has an area of \pm 326 hectares, with the use of land for rice fields, ponds, yards and people's forest. In 2012 the population was 5,384 with the number of men and women as many as 2,355 and 3,029 respectively. The number of families were 1,595 households. This village had a relatively rapid population growth where the number of births reached 78 , and only 35 people died, 8 moved out, and 7 people moved in.

Based on these data, the current total population in Neglasari is 5,246, with men and women numbering 2,249 and 2,997 respectively. The number of people living in Naga village is 1,829 with men and women 1,005 and 824 respectively. Kampung Naga, as one of the parts of the current Hamlet according to Mr. Uron, Chairman of RT 01 RW 01, has a population of 315 with 108 households. However, this research found that the number of households in Kampung Naga was 100 with four families still living in one house. The overall number of people in accordance with the tally was 305 .

The difference in data could be due to the increase and reduction of the 
population that continues to occur. For example, not long ago the Lebe of Kampung Naga, Mr Ateng Jaelani died, whereas not long after that a baby named Rindi was born. The baby was the grand child of Mr. Uron chairman of RT Kampung Naga.

The research location was Kampung Naga which is administratively part of the territory of Neglasari Village. Although the population is only 305, they are unique indigenous communities compared to the surrounding population. This village becomes the center of the implementation of the customs of Sanaga community living in the surrounding region. The Sanaga community is not the object of study. They are only a comparison and data sources if the information cannot be obtained from members of the community who live in Kampung Naga. The unity of the people of Sanaga descent who live inside and outside Kampung Naga serve as the source for the customs there.

The Sanaga community lives in the surrounding area of Kampung Naga, especially in the village of Nangtang, Nangkabongkok, Jahiang, Bongas, and other areas of Neglasari. In addition, they are also live in several cities such as Tasikmalaya, Garut, Bandung, Bogor and Jakarta. During the time of the performance of the Hajat Sasih ritual, they will return to Kampung Naga to join other Sanaga residents. Another term for Sanaga community is Seuwe Putu Naga (descendants of Kampung Naga).

\section{RELIGIOUS TEACHINGS EMBEDDED IN THE LIFE CYCLE RITUAL}

The rituals and celebrations held at Kampung Naga related to the life cycle range from pregnancy, birth, gusaran, circumcision, marriage and death. As a community that has a tradition passed down through generations, they do it attentively and enthusiastically. Local religious values have also been combined into the rituals as part of the life cycle. Unlike in other places, in Kampung Naga, the ritual of life cycle rarely is hardly exposed so it is not widely known by the general public.

The Selamatan of pregnant women is held in the seventh month of pregnancy. This ritual serves as an expression of gratitude and prayer that the unborn child until birth. In this ritual, people recite verses of the Qur'an especially sura Yusuf and Maryam hoping that children born later will be as handsome as Joseph or and as beautiful as Maryam. The recitation of the Qur'an is usually done by seven people invited specifically because of their fluency. Before the recitation starts, first, Mr. Danu as a theologian, performs tawasulan and prayer for the good of the baby. Then, seven different people who attend will recite the Qur'an with their respective division of verses. The suras commonly 
recited are Sura Yusuf, Maryam, al-Kahf, al-Mulk, and Yasin. It normally takes approximately one hour to read the entire sura in the Quran. Then, Mr. Danu delivers prayer to close this ritual, and a meal (ngariung) is served as a closure. In this ritual, the family of the baby provides a variety of ritual properties that have been prescribed by Indung Beurang. These properties will be used by the baby's mother, such as water, flowers, needles, thread and other equipment that will be placed on a nyiru. The nyiru will then be placed in the middle of the people reciting the Qur'an until completion of the event. The water that has been recited upon with the Quran verses will then be used for bathing so that the baby in the womb will survive and get blessing.

Childbirth is highly expected by the community of Kampung Naga so the process is welcome with joy. Welcoming the birth of a baby is done by selamatan (prayer ritual) as a form of thanksgiving to Allah who has bestowed a child to a family. The selamatan is done by inviting the neighbors to pray for the baby, giving a name to the baby and finally ended with eating meals together. Currently in Kampung Naga, the birth process is performed by midwives assisted by village traditional midwife (paraji).

The circumcision ritual is a process in the life cycle for Kampung Naga community that must be performed as part of Islamic requirement for a man. Circumcision in Kampung Naga is called sepitan or ngislamkeun. It is called sepitan because in the past, the process required pinning a man's genital organ before cutting the outer skin portion. Meanwhile, it is called ngislamkeun because it is a process that complements for a man's the Islamic faith. A circumcised man will be spared from any form of dirt so that when he performs prayer, it will be legitimate and perfect.

In this village the circumcision ritual is performed in conjunction with gusaran which is circumcision for girls. The tradition of circumcision is usually held in the month of Rayagung (Dzulhijjah in Islamic calendar), but the author also witnessed it was implemented in hapit (Dzulqaidah). To the community of Kampung Naga, Rayagung is believed a good month to carry out rituals. They believe that a boy who would be circumcised must be accompanied by a girl, because the girl is a shadow of the boy, so circumcision is always accompanied by gusaran for girls. The tradition of circumcision in Kampung Naga is usually jointly performed in order to make it more celebratory. The stages for sepitan (circumcision) and gusaran ceremony in Kampung Naga will be described here. 


\section{a) Bebersih}

Similar to the participants in the Hajat Sasih ritual, those taking part in gusaran and circumcision ceremony are required to perform bebersih or bath ritual. The bebersih ritual is performed on the Ciwulan river. The participants are children who will be circumcised accompanied by his mother and father. Together with them are also girls who perform the gusaran and their parents.

The bebersih ritual begins with the reading of prayers by a Kuncen or other people such as Indung Beurang. When prayer is done, the head of participants taking part in circumcision and gusaran will be rubbed with water mixed with the leuleur liquid (liquid soap substitute), then immediately followed by each parent bathing their children before circumcision. Some parents of participants taking part in circumcision also take a bath, and some just wash their head with herb and rinse it with water from the Ciwulan river.

After the ritual is done, the participants then return to their respective homes and change their children's clothes (usually with taqwa clothing), then walk to the mosque. When the ritual starts, the Kuncen will sit near the pulpit delivering a speech, followed by greeting each child in the ceremony. The kuncen will also greet the parents one by one while giving advice and quick prayer. Before starting the circumcision and gusaran ceremony, the kuncen, lebe and village elders will recite prayers. The first ritual concludes with a meal eaten together. Each of these parents and their children get a piece of dish placed on a rigen (a palate made of leaves).

b) Parade around the village

After completing the first ritual, the next stage is to take the participants of gusaran and circumcision to parade around the village. This event begins when traditional leaders and elders Kampung Naga walked hand in hand out of the mosque. They are followed by the parents of participants of circumcision and gusaran ceremony by carrying their children on the shoulders. Meanwhile in front of the mosque, several other residents begin to play typical instruments of Kampung Naga community, consisting of angklung and terebang sejak. The kuncen and the elders on the front row walk slowly, accompanied by the patunggon carrying offerings with them.

c) Ngala beas

Ngala beas literally means "taking rice". The ceremony is held after the entire group return to their own place. In the middle of the field, the kuncen and people accompanying him will be greeted by five middle-aged women who 
have waited there. They pound the alu (pestle) into the lisung (a place for grinding rice), to indicate that the ngala beas ceremony is ready to start.

The properties of ceremony consist of eight pieces of shroud, three pieces of fabric worn by women called samping kebat, three pieces of headbands or iket and tamaya (panganggo). Inside the boboko carried by the patunggon is white rice or beas bodas and sticky rice. Later, after the rice is boiled, it is distributed to the children that will be circumcised. Facing the lisung, the kuncen then recites prayers in the presence of Kampung Naga community elders and other participants.

d) The peak of the ceremony and scrambling for sawer

The height of the gusaran ceremony on the first day concludes with a return to the front side of the mosque. Each child while being held by his/her mother is called on to approach a paraji. A paraji is a traditional midwife or traditional circumcision "paramedic" in Kampung Naga, usually female. The paraji then washes her left hand into the rice water mixed herb leaves jawer kotok, panglai, onions, tektek or betel leaves, and chicken eggs are stored inside a black plastic bucket. Water is then washed on the forehead of the participants of gusaran. Next, the paraji shaves fine hairs on the forehead of the participants using a dagger. The event is accompanied by bela ceremony. Outside, on the yard of the mosque, several men are holding chickens and slaughtered them and shouted "belaaaaa!" Children whose forehead has been cleared of fine hairs will then be decorated by the parajis maid while asking them to bite the coins made in the Dutch period.

Children who have completed the procession then march around the village, following lekasan ceremony. Before returning home, the last event held on the first day is a ritual of sawer. This event is accompanied by verses of songs containing advice about life. Occasionally, after one verse is sung, rice--mixed with turmeric slices candy and coins-- is thrown to the crowd, and the crowd will be is busy fighting over candy and coins thrown at them.

\section{e) Wawarian}

The actual implementation of circumcision is performed on the following morning. A special knife is used in circumcision for boys, while for the girls, needles are used. After the whole procession is completed, the ceremony is closed with a wawarian. Trash and leftovers of the activities such as household waste will be collected at the shelter and then burned. This is what wawarian is all about; they are trying to maintain a healthy environment. 
The implementation of circumcision and gusaran ritual in the Sanaga community is almost similar. The bebersih activity is carried out in the public bath, while the whole series of ritual is centered an the place of the participant. The difference is that outside the village people normally hire some musicians or gamelan as entertainment for the invited guests.

The wedding celebration is performed by the community of Kampung Naga with full reverence. As a sacred event, the wedding day should be carefully chosen in accordance with the heritage of the ancestors. Wedding cannot be held in certain months and on the ill-fated days. For example it cannot be held in the months of Muharram, Sapar and Mulud or on the day of birth, or on the day one's parents died.

Wedding traditions in Kampung Naga begins with a proposal by the man, followed by choosing the wedding day (musytari). The procession begins with the ritual of ngeuyek seureh at night before the nuptials. The ceremony is held at the mosque by inviting the officials of Religious Affairs Office of Salawu. Then, the newlyweds return home and perform the customs of Sawer, Sungkeman, ngampar and Munjungan. The complete research on marriage can be found in the social system of Kampung Naga.

Death is inevitable for all beings, and the community of Kampung Naga believes that it is a natural way to eternity. So when someone dies, soon he will be laid in the funeral home facing north or south. Near the head of the dead body, people usually place an oil lamp, incense burned on the parupuyan, and the Qur'an. The neighbors and friends attend Yasin recitation to provide a bright path for the deceased. Women come with rice as a donation to the deceased family. Because many guests usually come, neighbors help with cooking for the guests and the people who take care of the dead body.

The prayer held for the dead body is in Kampung Naga is similar to that in other places. In the past, only a few (2 or 3 ) people led the prayer, not because of the small number of population at the time but it was due to the requirement that only very religious people could perform the prayer. Before the prayer starts, first incense is burnt near the head of the deceased. The Imam leads the prayer by standing on a piece of golden banana leaf. The use of banana leaf is a form of carefulness in maintaining the sacredness. The use of the banana leaf freshly picked ensures purity so it is expected that the prayer will be valid and accepted by God. Golden banana symbolizes the nature of the shiny yellow gold, so it will be able to light the way for the deceased in the hereafter.

Each person taking part in the prayer is given an envelope containing IDR ,5000 (five thousand rupiahs). If the family of the deceased is rich, they will 
give shalawat to all the villagers, especially children. In addition they will also slaughter a goat and distribute janteke which is donation from deceased relatives in the form of rice and meat. Giving shalawat is actually dependent on the economic condition of the deceased family, but there is a belief that the dead man needs a reward, so shalawat in the form of charity money or rice and meat should be distributed.

The Kampung Naga community also believes that a person who dies is mulih $k a$ jati mulang ka asal or returning to nature where the human spirit was once located. In order for the return journey of the deceased easy and well-lit, people hold certain rituals to accompany the journey. Elsewhere, tahlilan is held on the $3^{\text {rd }}, 7^{\text {th }}, 21^{\text {st }}, 40^{\text {th }}, 100^{\text {th }}$ up to $1000^{\text {th }}$ day and every year and every eighth year. In Kampung Naga, after a person dies, the family will invite a few neighbors who are fluent in reciting the Qur'an. It is held on the $3^{\text {rd }}, 7^{\text {th }}, 21^{\text {st }}$ and $40^{\text {th }}$ day after death.

The ritual of the Qur'an recitation is performed by gathering at the home of the late by first reciting certain prayer led by the Lebe or his representative. After that each person recites the Qur'an with the amount of recitation depending on the number of people present. For example, if there are 10 people, then 30 chapters will be divided into ten and completed around 3 nights. After completion of the Qur'an recitation, it is followed by eating meals and the family of the deceased will give out some money as shadaqah of which the reward is expected to be given to the deceased. The recitation of the Qur'an (30 chapters in all) will be repeated on $7^{\text {th }}$ and $40^{\text {th }}$ day. After that there is no more ritual.

However, the observations conducted by the author showed that the Sanaga residents in Nangtang and Nangka Bongkok village held the recitation on the $100^{\text {th }}$ day and one year after a member of a rich family dies. In fact, it could be held when the death period has reached the eighth year. In this ritual, especially on the $40^{\text {th }}$ day, and if the family is rich, they will slaughter goats and distribute to nearby neighbors, especially those who participate in the recitation of the Qur'an in the evening. Slaughtering the goat for the people who have died is called nyusulan i.e. a supplementary shadaqah for the deceased to get the reward.

Interview with a resident of Kampung Naga, Kang Iin Sholihin, who often participated in the tahlilan revealed that recitation of the Qur'an is performed several times after a person's death; 1) poena, the day after death, 2) Tiluna, the third day after death, 3) Tujuhna, the seventh day after death, 4) Opat puluh, the fortieth day after death, 5) Natus, the one-hundredth day after death and 6) Newu, the one-thousandth day after the death. Based on the information 
collected, the community of Kampung Naga also held recitation of the Qur'an after death. If the family can afford it, it is advisable to slaughter a goat as ikah for the deceased. The annual celebration is also held if the family can afford it.

The people in Kampung Naga today are not allowed to build a wall on the grave or a tombstone on top of the cemetery (tetenger). This practice has been around since the times of their ancestors. A tomb in this village is a stone placed at the head and feet or a piece of wood carved with the person's name (called satangtung stone). The funeral is adjusted to the descendants or families of deceased. With regard to the grave visit, the Kampung Naga community has a tradition of visiting the Astana Gede or great cemetery together which is located on west of the village. It takes place every Muharram, especially on Friday. The whole community of Kampung Naga both men and women visit the tomb of their respective families. They clean up the location of the cemetery, but first a prayer is performed by the Kuncen. The grave visit for them is one of the forms of worship to pray for the dead, and at the same time, to remind them of death. One of the characteristics of this community is that that their grave is not cemented or bricked. It is considered taboo because it was never done by their ancestors. No wonder the cemeteries in this area are not cemented or have tombstone placed on it.

\section{CONCLUSION}

Several conclusions can be drawn from discussion of the life cycle ritual in Kampung Naga above. First, they carry out the ritual a form of adherence to traditions inherited from their ancestors. The ritual is performed with full reverence, and they believe that when they do it, they have respected their ancestors. The life cycle ritual in this village is unique compared to other regions. This is due to the fact that there is no change in the procedures for its implementation. They do not dare to add new things that were not included previously. In addition they are also unwilling to accept things outside their culture especially those incompatible with the system of their culture.

Basically, the life cycle ritual performed by the community of Kampung Naga is almost the same as other the tradition of Sundanese communities particularly the ritual to keep the fetus in the womb will be born in good health. The rituals of akika and naming giving are an expression of thanksgiving because of the long-awaited child born safely. Meanwhile, the rituals of circumcision and wedding are performed as a form of joyfulness. Whereas, the death ritual is the prayer of those who are left behind for people who have died to get a 'bright path' and happiness in the hereafter. 


\section{REFERENCES}

Abdul Rozak, 2005, Teologi Kebatinan Sunda, Bandung: PT Kiblat Buku Utama.

Ahmad Gibson AlBustomi, "Islam-Sunda Bersahaja di Kampung Naga". Posted on http://sundaislam.wordpress.com/2008/01/12/islam-sunda-bersahaja-di-kampung-naga/

Ahman Sya, M,dkk. 2008. Sejarah Kampung Naga. Bandung: Dinas Kebudayaan dan Pariwisata Provinsi Jawa Barat Balai Pengembangan Kemitraan dan Pelatihan Tenaga Kepariwisataan.

Amalia, Lia, 2001. Upacara Adat Hajat Sasih Pada Masyarakat Kampung Naga Kajian Fungsionalisme. Malang: Skripsi di Universitas Negeri Malang.

Astuti, Budi, 2002. Upacara Adat Hajat Sasih Masyarakat Kampung Naga Akulturasi Budaya Islam-Sunda (1950-2001) Yogyakarta: Skripsi di Universitas Negeri Yogyakarta.

Beatty, Andrew, 2001, Variasi Agama di Jawa: Suatu Pendekatan Anthropologi, Jakarta: Rajagrafindo Persada.

Bungin, B. 2003. Analisis Data Penelitian Kualitatif. PT Rajagrafindo Persada: Jakarta.

Connoly, Petter (editor), 2011, Aneka Pendekatan Studi Agama, Yogyakarta: LkiS.

Creswell, J. W. 1998. Qualitatif Inquiry and Research Design. Sage Publications, Inc: California.

Darsa, Undang A. Dan Edi S. Ekadjati. 2006. Gambaran Kosmologi Sunda. Bandung: PT Kiblat Buku Utama.

Dhavamony, Mariasusai. 1995. Fenomenologi Agama, edisi ke 10. Yogyakarta: Kanisius

Ekadjati, Edi S., 2009. Kebudayaan Sunda: Suatau Pendekatan Sejarah, Jilid 1, Jakarta: Pustaka Jaya.

Emzir, 2010, Metodologi Penelitian Kualitatif : Analisa Data, Jakarta : Rajagrafindo Persada.

Fetterman, David M. 2010, Ethnography: step-by-step, London: Sage Publication Inc.

Giri MC, Wahyana, Sajen dan Ritual Orang Jawa, Yogyakarta: Penerbit Narasi.

Ihromi, T.O. (editor), 2006, Pokok-pokok Antropologi Budaya, Jakarta: Yayasan Obor Indonesia.

Iqbal, Muhammad, dkk. 2008. Kunjungan Kebudayaan Daerah: Kampung Naga. Bandung: Fakultas Tekhnik Universitas Pasundan.

Kluckhohn, Clyde. 1942. "Myths and Ritual: A General Theory", dalam Harvard Theological Review, XXXV. 
Koentjaraningrat, 1985, Kebudayaan Mentalitas dan Pembanguan, Jakarta: PT Gramedia

Koentjaraningrat, 2002. Pengantar Ilmu Antropologi, Jakarta: PT. Rineka Cipta.

Koentjaraningrat, 2007. Sejarah Teori Antropologi I dan II, Jakarta : Penerbit Universitas Indonesia Press.

Kusnendar, Yogi Hendra, 2008. Da'wah Dan Tradisi Lokal (Studi Hajat Sasih Pada Masyarakat Adat Kampung Naga, Tasikmalaya dan Strategi Da'wah Terhadap Masyarakatnya. Jakarta : Skripsi di Sekolah Tinggi Ilmu Dakwah Muhammad Natsir.

Lubis, Nina Herlina (ed.). 2003. Sejarah Tatar Sunda, Bandung: Pusat Penelitian Kemasyarakatan dan Kebudayaan Lemlit UNPAD

Maria, Siti. dkk. 1995. Sistem Keyakinan Pada Masyarakat Kampung Naga Dalam Mengelola Lingkungan Hidup (Studi Tentang Pantangan dan Larangan). Jakarta: Proyek Pengkajian dan Pembinaan Nilai-nilai Tradisional Direktorat Jenderal Kebudayaan.

Mattew B Milles. A Michael Huberman, 2007, Analisis Data Kualitatif, UI Press

Moleong, Lexi J, 2006. Metodologi Penelitian Kualitatif, Bandung : PT. Remaja Rosda karya.

Nasution, Harun, 2010, Islam Ditinjau dari Berbagai Aspeknya, Jakarta: UIPress.

Nugraha, Angga. 2011. Makna Simbol Komunikasi Dalam Upacara Hajat Sasih. Bandung : Fakultas Ilmu Komunikasi Universitas Padjadjaran.

Nur Syam, 2007, Madzhab-madzhab Antropologi. Yogyakarta: LKiS Pelangi Aksara

Nur Syams, 2005, Islam Pesisir, Yogyakarta : LKIS

Purwitasari, Tiwi. 2006. "Pemukiman dan Religi Masyarakat Megalitik: Studi Kasus Masyarakat Kampung Naga, Jawa Barat", dalam Arkeologi dari Lapangan ke Permasalahan. Jakarta: IAAI.

Saringendyanti, Etty. 2008. Kampung Naga, Tasikmalaya Dalam Mitologi: Upaya Memaknai Warisan Budaya Sunda, Bandung: Laporan Penelitian di Universitas Padjadjaran.

Soekanto, Sarjono, 1990. Sosiologi Suatu Pengantar, Jakarta: Rajawali Pers. Spradley, James P. 2007, Metode Etnografi, Yogyakarta: Tiara Wacana

Suganda, Her. 2006. Kampung Naga: Mempertahankan Tradisi. Bandung: PT Kiblat Buku Utama

Suhandi Shm., A. 1982. Penelitian Masyarakat Kampung Naga di Tasikmalaya. Bandung: Skripsi di Universitas Padjadjaran.

Suprayogo, Imam dan Tobroni, 2001, Metodologi Penelitian Sosial-Agama, 
Bandung: PT. Remaja Rosda karya.

Suriasumantri, Jujun, 2001, Filsafat Ilmu: Sebuah Pengantar Populer, Jakarta: Pustaka Sinar Harapan

Suryani NS, Elis dan Anton Charliyan, 2010. Menguak Tabir Kampung Naga, Tasikmalaya : CV. Danan Jaya.

Yandi, Harpat Ade, 2008. Pelaksanaan Hukum Kewarisan di Lingkungan Adat Kampung Naga Desa Neglasari Kecamatan Salawu Kabupaten Tasikmalaya ditinjau dari Hukum Islam, Yogyakarta : Skripsi di Fakultas Syariah Universitas Islam Negeri Sunan Kalijaga.

Yulandita, Lastriyana, 2011. Pola Komunikasi Dalam Pelestarian Kampung Adat Suku Naga. Bandung : Fakultas Ilmu Komunikasi Universitas Padjadjaran. 